\section{Ageing Entrepreneurs and Business Transfer Challenges in Croatia}

\section{Petra Mezulić Juric}

Faculty of Economics, Josip Juraj Strossmayer University of Osijek, Osijek, Croatia

pmezulic@efos.hr

\section{Mirela Alpeza}

Faculty of Economics, Josip Juraj Strossmayer University of Osijek, Osijek, Croatia

malpeza@efos.hr

\section{Sunčica Oberman Peterka}

Faculty of Economics, Josip Juraj Strossmayer University of Osijek, Osijek, Croatia

suncica@efos.hr

\begin{abstract}
Business transfer as a research topic awakened the interest of researchers in the past few decades. Business transfer is defined as a change of ownership of any firm to another person or legal entity assuring the continuous existence and commercial activity of the enterprise, and it encompasses different kinds of transfers both to family and non-family members. Ageing and consequently retirement are often mentioned as the reasons for entrepreneurs' exits from the companies and intention to initiate the business transfer process. A successful business transfer process is one of the key prerequisites for longterm sustainability of small and medium-sized enterprises. There is a significant number of ageing business owners in Croatia who will exit their companies in the coming years. Considering the number of these entrepreneurs and the influence their exits can have on company stakeholders and national economy in general, it is of great importance to better understand the factors that can influence the choice of their exit strategies. The aim of the paper is to provide an understanding of the dilemmas that the ageing entrepreneurs face when considering different exit modes. The data for the study was collected through in-depth, semi-structured interviews conducted with six ageing business owners. The analysis of the interviews enabled the identification of the challenges that ageing entrepreneurs face in the business transfer process: emotional attachment to the firm, strong preference for family succession and concerns about financial security after retirement. Some of these challenges are a result of the undeveloped business transfer ecosystem, strong tradition and cultural values that imply family succession as the only acceptable exit strategy for retiring company owners in Croatia.
\end{abstract}

Keywords: business transfer, entrepreneurial exit, ageing entrepreneurs, SMEs, business transfer ecosystem
ORIGINAL SCIENTIFIC PAPER

RECEIVED: APRIL 2019

REVISED: JANUARY 2020

ACCEPTED: FEBRUARY 2020

DOI: 10.2478/ngoe-2020-0002

UDK: 658.114.1:159.922.63(497.5)

JEL: L53, L21

Citation: Mezulić, Juric, P., Alpeza, M., \& Oberman Peterka, S. (2020). Ageing Entrepreneurs and Business Transfer Challenges in Croatia. Naše gospodarstvo/Our Economy, 66(1), 13-22. DOI: 10.2478/ngoe-2020-0002

\section{NG OE}

NAŠE GOSPODARSTVO OUR ECONOMY

\begin{tabular}{l|l|l|} 
Vol. 66 & No. 1 & 2020 \\
\hline
\end{tabular}

pp. $13-22$ 


\section{Introduction}

The SME business transfer as a research topic awakened the interest of researchers in the past few decades. Business transfer is defined as a change of ownership of any firm to another person or legal entity assuring the continuous existence and commercial activity of the enterprise when more than $50 \%$ of assets or shares are transferred (Van Teeffelen, 2010). The definition of business transfer encompasses different kinds of transfers both to family and non-family members. Ageing and consequently retirement are often mentioned as the reasons for entrepreneurs' exits from the companies and initiating business transfer processes. Ageing, in general, is considered to be one of the greatest social and economic challenges of the 21st century in Europe. The proportion of people aged 65 or more is expected to increase from $19.8 \%$ in 2018 to around 31.3\% by 2100 (Eurostat, 2019). The ageing of the European population also translates into the ageing of the European entrepreneurs impacting the transfer of enterprise ownership but also employment and growth prospects (Varamäki \& Viljamaa, 2014). A macroeconomic study in the Netherlands showed that, in 2011, nearly $10 \%$ of all SMEs either liquidated or were up for sale, mainly for retirement reasons (Van Teeffelen \& Uhlaner, 2013).

Because of the high rate of risk in the implementation of the business transfer process in SMEs, the European Commission has been monitoring the quality of national business transfer ecosystems in EU member countries for the last 25 years, providing recommendations to policy makers for the improvement of support programs for entrepreneurs facing business transfer challenges (e.g. European Commission, 2011; 2013).

The issue of business transfer is particularly important for post-socialist economies in Europe, in which the transition to a free-market economy in the early 1990s encouraged the launching of a significant number of entrepreneurial ventures. Nearly three decades later, first-generation entrepreneurs who started businesses in the 1990s have reached the age when they should plan for retirement, and thus make a decision about the future of the company after their withdrawal from the business. Unlike developed countries, which have a long tradition of entrepreneurship and private ownership, post-socialist countries in Europe are facing the first major wave of entrepreneurial exit and transfer of businesses. Despite the importance of this topic for national economies, challenges faced by first-generation entrepreneurs and level of development of the business transfer ecosystem are still an under-researched topic. One of the first academic contributions to addressing the specificity of issues related to family business succession in the transition economies was done by Dana and Ramadani in 2015 as editors of the book "Family Businesses in Transition Economies - Management, Succession and
Internationalization.” The contributions for this edition came from authors from Slovenia, Bulgaria, Moldova, Croatia, Macedonia, Czech Republic, Slovakia, Russia, Serbia and Kosovo, but with a rather heterogeneous approach to the topic.

The issue of business transfer is becoming increasingly important in Croatia. Based on the Business Transfer Barometer Croatia (BTBC) research in 2015 conducted by CEPOR - SMEs and Entrepreneurship Policy Centre - the share of enterprises whose owners are 55 years old or older in Croatia amounts to $31 \%$ of the total number of enterprises, with a share of $16.1 \%$ in the total number of employees in legal entities, and a share of $18.9 \%$ of the total income generated by legal entities (Alpeza et al. 2015, 15). Based on the results of this research, it was estimated that more than 5300 enterprises in Croatia, with about 57,000 employees, represent a risk group where owners underestimate the complexity and length of the business transfer process. This can have significant negative implications for those firms, their owners as well as a wide network of stakeholders - employees, firm owner's family members, suppliers, customers, banks, local business environment and the national economy in general (European Commission, 2002; 2011). The aim of this paper is to provide a deeper understanding of the challenges and dilemmas the ageing entrepreneurs are facing when considering different business exit modes in Croatia, a country with an undeveloped business transfer ecosystem (Viljamaa et al., 2015). The research results provide a basis for revisiting the policy recommendations for supporting the SME owners in the business transfer process created in 2015 by CEPOR: launching of awareness raising activities, development and co-financing of advisory services, defining and supporting the development of family entrepreneurship, promoting and co-financing business takeover, and developing of virtual matching services for sellers and buyers of SMEs.

\section{Literature Review}

Exploring the business transfer challenges of ageing entrepreneurs requires a deeper insight into the previous research results in the field of entrepreneurial exit, business exit strategies, ageing and retirement of entrepreneurs.

Entrepreneurial exit is the important phase of the entrepreneurial process (DeTienne, 2010). In spite of this fact, most of entrepreneurship research but also policy attention and supporting programs so far have been focused on new venture creation and growth of the company and little attention has been given to entrepreneurial exit.

Research and theory on entrepreneurial exit focus mainly on two units of analysis: individuals and firms (Aldrich 
2016, 11). When firms represent the units of analysis, exits can be analysed at several levels - exits of founders and founding teams, new ventures, new populations and the aggregation of populations at the level of the total economy. When individuals are taken as the unit of analysis, researchers focus on the founders of the entrepreneurial ventures, but also owners who may not necessarily have founded the business (Aldrich 2016, 11). The focus of this paper is on the individual level of analysis, rather than the firm. In that context, entrepreneurial exit is defined as the process by which the founders of privately held firms leave their companies, thereby removing themselves, in varying degrees, from the primary ownership and decision-making structure of the firm (DeTienne, 2010). A better understanding of entrepreneurs' challenges in this process is of great importance. According to Sarasvathy (2004), entrepreneurship researchers' attention needs to be focused on understanding entrepreneurs' point of view.

Compared to business transfer, which refers in its definition to change of ownership only, entrepreneurial exit encompasses two dimensions, namely entrepreneur's withdrawal from both ownership and (key) management role in a company. However, the study of entrepreneurial exit needs to be incorporated into the study of business transfer since predecessors play the key role in the business transfer processes. Business transfer as a concept includes the sustainability of the company, which tends to be one of entrepreneurs' biggest concerns when considering different exit options (Alpeza et al., 2015). There are several different exit options for entrepreneurs to consider when leaving their companies, including family succession, sale to individuals or other companies and liquidation (Deschamps, 2012). It is important to understand why entrepreneurs choose different exit strategies. DeTienne and Chandler (2010) state that the length of time required to complete the entrepreneurial exit process from the company is directly related to the complexity of the business and the circumstances underlying the decision to exit. Also, there is a variety of personal and organisational factors that can influence the time and the way the entrepreneur will exit the company (Delmar et al., 2006; Taylor, 1999). Taylor's study (1999) shows that entrepreneurs' personal factors related to entering the entrepreneurial venture affect how the entrepreneur is going to exit from the business. DeTienne and Cardon (2010) showed that variables such as age, education level and industry experience influence entrepreneurs to pursue different exit paths.

Ageing and closing to retirement age are unavoidable triggers for business transfer (European Commission, 2002, 2011; Van Teeffelen \& Uhlaner, 2013; Koładkiewicz \& Wojtyra, 2016). However, there are also some other reasons that can stimulate entrepreneurial withdrawal from the business, such as change of profession and personal interests, willingness to start another entrepreneurial venture, changes in the business environment that require significant changes in the business model that the entrepreneur is not capable or willing to introduce or incidental situations, like divorce, illness or death.

Some of the researchers link retirement to the development of strong emotions, such as fear, anxiety or uselessness (Feldman \& Beehr, 2011). Emotional attachment can prevent a positive exit outcome (Van Teeffelen, 2012) and delay or postpone transfer of business (e.g. Lansberg 1999; Sharma et al. 2001), especially in family businesses where it is identified as the major obstacle to successful transfer (Sharma et al., 2003). Some of the researchers highlighted the existence of psychological barriers to business transfers, such as fear of mortality, fear of nothingness and losing a part of the identity, prejudice against succession planning and distrust of the successor (Lansberg, 1988; Steingold, 2012; Flören \& Nandram, 2007, Van Teeffelen et al., 2011; Weesie, 2017), and only recently the coping strategies to those barriers in context of business transfers were further explored (Weesie, 2017). Based on his research, Weesie concluded that between passive and active coping styles, entrepreneurs will dominantly use passive style, such as denial, focus on and venting of emotions or substance use. Soleimanof et al. (2016) use the theory of planned behaviour to build the conceptual model linking retirement intentions to exit effort and strategy. The developed model indicates that "retirement intentions are a key factor influencing exit effort and its interactions with exit strategy."

As previously mentioned, the study of entrepreneurial exit is closely linked to the study of business transfer. This fairly new phenomenon was introduced in 1980s through the issue of business succession planning, primarily by researchers focused on family entrepreneurship. Family business researchers addressed the issue of succession planning as one of the most important reasons why many first-generation family firms do not survive their founders (e.g. Lansberg, 1988). In the 1990s, researchers continued to focus on family business and the issue of succession and survival through the creation of models of succession determinants (Morris et al., 1997), and, in the 2000s, through the creation of integrative models of the succession process (Le Breton-Miller et al., 2004). Family succession seems to be the most studied exit strategy of entrepreneurs (e.g. Lansberg, 1988; Bennedsen et al., 2007). According to the existing evidence, family succession accounts from around 15\% to $35 \%$ of businesses transfer processes, and the numbers have been declining (CSES, 2013).

Business transfer and exit preferences of entrepreneurs have been researched in Croatia through the already mentioned Business Transfer Barometer research. In this research, the main identified challenges among entrepreneurs are related to maintaining harmonious relations within the family while going through the business transfer process 
and identification of sources of income after the withdrawal from the company (especially in family succession cases). The same research also indicated a low level of understanding of the complexity of business transfer among Croatian entrepreneurs and a difficulty in identifying the professionals whose expertise might be helpful in coping with the business transfer challenges, especially in the micro and small business sector. This finding was also mentioned as a weakness of the Croatian business transfer ecosystem in the analysis of business transfer ecosystems of five European countries (France, Spain, Finland, Sweden and Croatia) conducted by Viljamaa et al. in 2015. The same authors found that legal and tax regulations are the only favourable components of the Croatian business transfer ecosystem that do not present a barrier for business transfer processes. Other parts of the business transfer ecosystem, as identified by Van Teeffelen (2010), namely sellers, buyers, financial institutions, advisors, market and economic conditions and tax regulations, according to Viljamaa et al. (2015), are still undeveloped in Croatia, representing more an obstacle than the supporting factor in business transfer processes. Lack of adequate sources of financing and government subsidy programs for business takeover, scarcity of professional advisory expertise related to business transfer for micro and small business owners and lack of online matching platforms that would facilitate the establishing of contacts among sellers and buyers of SMEs represent the biggest differences of the Croatian business transfer ecosystem compared to the situation in more developed European countries (Alpeza et al., 2018).

\section{Methodology}

For the purpose of exploring the ageing entrepreneurs' challenges and dilemmas when considering different exit strategies, the case study method was applied. The case study method was chosen because while it is descriptive in its essence, it enables the understanding of the dynamics that exist within a single setting and the explanation "why" behind the decisions and relationships (Yin, 2014; Eisenhardt, 1989). The purposive sampling method was used for the selection of cases. Eisenhardt (1989) argues that the selection of an appropriate population controls extraneous variation and helps to define the limits for generalizing the findings. Six small business owners aged 55 years or older from four companies who attended at least one business transfer awareness raising event were selected as a sample in this research. They were chosen because they were already familiar with the concepts of exiting the company and business transfer. Another reason was that the participation at the awareness raising event encouraged them to think further about exiting the company and, at the same time, about the future of their companies once they have withdrawn from it.

The selected owners were company founders with both ownership and managerial role in their companies. The sample included owners who have family members (children) involved in their business as well as those who do not. The general information about the interviewed ageing owners and their companies is presented in Table 1.

The case studies in this paper were built based on qualitative data collected through in-depth, semi-structured interviews and observations by two researchers working as a team. One of the researchers was handling the interview questions and the other was responsible for recording the interviews and observing the interviewees' reactions. As suggested by Eisenhardt and Bourgeois (1988), this approach enables the interviewer to establish the perspective of personal interaction with the interviewee, while the other researcher retains a different, more distant view. Semi-structured interviews enabled researchers to ask the owners a standard set of questions but also probe the

Table 1. Sample of companies with ageing entrepreneurs

\begin{tabular}{|c|c|c|c|c|c|c|}
\hline Interviewees & Case & $\begin{array}{l}\text { Entrepreneur's } \\
\text { age }\end{array}$ & $\begin{array}{c}\text { Company } \\
\text { founding } \\
\text { year }\end{array}$ & Industry & $\begin{array}{l}\text { Number of } \\
\text { employees }\end{array}$ & $\begin{array}{l}\text { Number of children/number of children } \\
\text { involved in company operations }\end{array}$ \\
\hline IN1 & A & 59 & 2003 & Food processing industry & 6 & 3/all involved in some way \\
\hline IN2 & B & 64 & 1996 & Engineering & 30 & 3/not involved \\
\hline IN3 & $\mathrm{C}^{*}$ & 56 & 1989 & IT industry & 6 & $1 /$ not involved \\
\hline IN4 & $\mathrm{C}^{*}$ & 64 & 1989 & IT industry & 6 & $1 /$ not involved \\
\hline IN5 & $D^{*}$ & 61 & 1997 & Specialied retail shop & 3 & 3/1 involved \\
\hline IN6 & $D^{*}$ & 65 & 1997 & Specialized retail shop & 3 & 3/1 involved \\
\hline
\end{tabular}

*Companies described in case $\mathrm{C}$ and $\mathrm{D}$ have multiple owners. Company in case $\mathrm{C}$ has 4 co-owners -2 of them were interviewed. Company in case D has 2 co-owners, who were both interviewed for the purpose of this research.

Source: Own transcripts of interviews. 
interviewee for additional details. in the in-depth interviews helped to gain a better understanding of the decision-making process in the pre-transfer phase and determine the factors that influence the business owners in considering different exit modes. The interviews lasted between 80 and 120 minutes, and were conducted between October 2016 and January 2017 on the premises of CEPOR - SMEs and Entrepreneurship Policy Centre - that organized the awareness raising workshops about business transfer challenges in which the interviewees participated.

The interview protocol consisted of two major parts. In the first part of the interview, the entrepreneurs were asked to talk about their entrepreneurial path and the companies they had created. The initial questions asked by the interviewer were: How did you start the business? How long have you been running the business? How is the business operating today?

In the second part of the interview, the participants were asked about the future of their company with the following initial questions: What do you think will be the future of your company after you retire? How would you like to exit your company? What is your exit strategy?

During the interview, additional questions were asked based on the information obtained from the interviewee. An adjustment of the data collection instrument was expected, which was the main reason why semi-structured interviews were chosen as the data collection method. These adjustments allow researchers to be flexible and take advantage of special opportunities which may present themselves in any given situation during the interview (Harris \& Sutton, 1986).

The multiple case study method enabled an in-depth analysis of each case as a stand-alone entity, as well as the searching for cross-case patterns in order to generalize the findings (Bourgeois and Eisenhardt, 1988). The analysis of the research results included a comparison between theory and data for the purpose of enhancing the internal validity and generalizability of the research results. The research conclusions were compared to the results and policy recommendations of the Business Transfer Barometer Croatia.

\section{Results and Discussion}

The information gathered from the first part of the interview, where the interviewees (IN1, IN2, IN3, IN4, IN5 and IN6) were asked to describe their entrepreneurial path, provided background information about the business owners and their companies (Case A, B, C and D).
Case A describes a situation of a small business managed by a 59-year-old owner who established the business 15 years ago. The company produces different kind of cakes sold through B2B and B2C channels and employs six people. The owner invested years in building a reputable business. Profit made by the company has been reinvested in new equipment and operation processes each year. The business owner's three children are involved in company operations. The oldest daughter is formally employed in the company. The other two children are not formally employed, but they would like to be more involved in business operations. The oldest daughter, who has finished high school, has the administrative job within the company and occasionally helps in production if the number of orders requires it. The middle daughter, who has a business school degree, has a good position in a bank, although she is thinking about leaving it after maternity leave and joining the family business. The owner's youngest son is a pastry chef and would also like to join the business. He is the one who has ideas about new products that the company could introduce to its customers. The owner is close to her retirement age and she has been thinking for some time about exiting the company and transferring the business to her children. Besides keeping a harmonious relationship among her family members, the owner is concerned about finding the best solution for her retirement. She expects to have additional sources of income from the company, besides her pension, which she expects to be very low and not adequate for a good standard of living, that she would like to have once she retires. The additional source of income, next to her pension, she believes should be calculated based on the value of the company whose ownership she plans to transfer to her children.

Case B illustrates the situation of a 64 year-old engineer and owner of a company specialized in electrical power engineering. The company has been successfully operating for the past twenty years and, in that time, it has gained respect among its customers and business partners. The company conducts business on the domestic market in Croatia, the European Union and eastern and southeast Asia. The business has been very profitable, especially in recent years. The owner has three grown up daughters who have all chosen different career paths and are not interested in continuing their father's business. The company has 30 employees, mainly engineers. retirement and wish to pursue a less stressful lifestyle made the owner think about the possible exit strategies. The owner has already discussed his intention to exit the business with his key employees and offered them to take over the company. None of the engineers are willing to take the company for two reasons: firstly, they are not willing to take over the risk of running the business and secondly, they lack financial resources required to buy the company. This situation puts 
the owner in a position where he has to think about selling the business to an external person or another company as his exit strategy.

Case $\mathbf{C}$ describes the situation of an IT business run by four partners (two married couples) who founded the business almost thirty years ago. Three of the founders have informatics engineering degrees and one of them has a business school degree. The company has developed its own accounting software and gained a significant number of clients throughout the years. In the mid-1990s, after the company was founded, the market was rapidly expanding and requiring specialised accounting IT solutions. At that time, the company experienced a fast revenue growth. In recent years, due to rapid changes in technology development and lack of initiative and knowledge of company co-owners, the company has not been capable to keep up with the competition and has experienced a decline in its revenue. The four company owners have started thinking about retirement and the future of their company. Each couple has one child and they are not involved in the business. Both children have recently graduated and, at that time, they have chosen different career paths. Besides the four owners, who are employed in the company, the company has two other employees who lack the required skills and knowledge to take over the business. The owners are currently considering their exit options. The main company product needs to be innovated, which requires knowledge, time and energy that owners do not have. If the owners do not have the capacity to innovate the software, they will lose their customers even before they retire.

Case D illustrates the situation of a small specialised shop selling orthopaedic products which is owned by a married couple. The owners are ageing entrepreneurs who started the business twenty years ago by selling orthopaedic shoes and different kinds of orthopaedic equipment. The company is also the exclusive importer for several reputable orthopaedic footwear brands sold in their store. The owners have gained customers' trust by offering high quality products and an individual approach to customers. The current owners were running the business by themselves. Last year, their daughter joined the family business. She has shown great passion for work as well as an interest in expanding the business. The owners also have two more children who are not involved in the business and have chosen different career paths. Both owners see their daughter as the potential successor but, at the same time, they are concerned about maintaining good family relations and gaining additional sources of income once they retire, next to their pension which they expect to be very low.

The analysis of the in-depth interviews conducted with six ageing business owners considering different exit strategies enabled a deeper insight into the challenges these entrepreneurs face. One of the challenges identified is their emotional attachment to the businesses they have created, which was already identified in the previous research (Sharma et al, 2003; Feldman and Beehr, 2011; Van Teeffelen, 2012, Weesie, 2017). A further analysis of the data collected through the interviews and observations in this research identified the main causes and fears influencing a high level of emotional attachment to the business as well as the consequences of such behaviour.

\section{Fear of identity loss}

Running a business is a way of life for the interviewed entrepreneurs, and they believe that business success depends on their involvement. They have closely connected their lives with their companies, and they fear losing their important position within the family as well as the community after they withdraw.

- "We have been living with this business all of our working life... it is our way of life." (IN3 and IN4)

- "I am facing the most important decision in my working life and the life of the company. If I decided to liquidate the company... I cannot come in and say that we are closing the operations next month... some of the projects are in their beginning stage, some are near their completion, and I have thirty people employed in my company." (IN2)

- "We love the business we created and the relations we have built with our customers." (IN5 and IN6)

- "I am the owner of the business, but at the same time, also the manager. I know the soul of this business." (IN2)

\section{Fear of losing financial security after leaving the company}

Due to low pension levels in Croatia, Croatian entrepreneurs face the challenge of low standard of living once they retire. This is also supported by previous research, which showed that more than $70 \%$ of entrepreneurs who are close to their pension would need additional financial resources once they retire (Alpeza et al., 2015). The average pension in Croatia ranged from EUR 330 in 2014 to EUR 360 in 2018 (Croatian Pension Insurance Institute, 2019). For most entrepreneurs, therefore, their personal income, coming from the profits generated by the company's future operations (if they transfer it to their children), represents an important additional financial resource for their retirement. The emotional attachment (although often considered as unreasonable) is rooted, in some of the cases, in their actual concerns as to their future financial security 
which depends on how well the company will perform in the future. Most of the entrepreneurs prefer family succession because they believe it is the best way to secure theirs and their family members' future wellbeing.

- "I think I need to secure the working position for both of my children who are not working in the company at this moment." (IN1)

- "We are thinking about retiring and transferring the business to one of our daughters... we are afraid that we are not going to have sufficient financial resources after our retirement... Our daughter does not have the means to buy the business from us... and there is no credit line to support her." (IN5 and IN6)

\section{Family succession as a preferred exit option}

A further data analysis indicated entrepreneurs' strong preference for family succession even though their children might have already chosen different career paths.

- "I want to retire and what I would like to do is to give the business to my children, but I keep wondering if it is better to transfer the business to one of them or all three of them? In my opinion, the best solution is to have one person as the owners of the company, but they are all my children." (IN1)

- "As we see it, there are three options for us... one is to liquidate the company, another is to transfer the ownership to someone younger and a third option is to talk to our children... We could liquidate the company... but it would be a shame to lose everything we have created... We would like to give the company to our children." (IN3 and IN4)

- "Our children have been living with this company ever since their birth, they have all the relevant information, but they have different preferences now... we see them as potential successors." (IN3 and IN4)

\section{Postponing the business transfer process}

The interviewed entrepreneurs are late in planning their business transfer, mostly because they rely too long on waiting for family successors to make their decision about taking over the family business, or because they are uninformed about the complexity and longevity of the business transfer process.

- "We started to think about how we are getting old and we should think about retiring... We should have thought about it earlier while there was still time... but, at that moment, we enjoyed it so much.” (IN3)

Previous research on business transfer emphasizes that preparation and planning of business succession is important for ensuring successful transfer and continuity of the firm (Le Breton-Miller et al., 2004; Ip and Jacobs, 2006). Proper and timely preparation enables addressing all the important questions related to the transfer. It also enables all relevant parties to have enough time to either withdraw from or grow into the business (Hytti et al., 2011).

Low level of preparedness for business transfer is a result of entrepreneurs' lack of knowledge and experience on the level of development of the business transfer ecosystem that should provide support in the implementation of the entrepreneur's chosen exit strategy. Entrepreneurs are not familiar with company valuation methods and have no information on the potential consultants providing that kind of expertise for micro and small companies.

- "Planning my exit is a current issue for me...If you want to sell something, it is also important to know what you are selling. You have some assets and some know-how... I don't know the value of my company and I need a person or a broker who could help me find the buyer... A broker with access to the market.” (IN2)

Another issue that entrepreneurs face is lack of financial services directed toward potential buyers.

- "If I ask my employees to buy my company, I need to offer them a solution... Not wanting to buy the company for personal reasons is one thing, and wanting to buy but not having the means to buy it is another." (IN2)

All of the above findings are in line with the previous research. An additional finding that was identified is the pressure put on entrepreneurs in Croatia to give their company to their children without any financial compensation. This approach in family succession is customary in Croatian culture and tradition. In this case, a strong cultural legacy affects the owner's decision in choosing the exit strategy. For the majority of entrepreneurs in Croatia, the pension level is too low, therefore the income from the company profits (in case of family succession) or company's sale (in case of selling the company) is the solution for the entrepreneur's financial wellbeing. It can be concluded that entrepreneurs' attachment to their companies is influenced by his or her fear of losing identity, fear of financial (in)security and family succession as a preferred option, which leads them to postpone their exit from the company (Figure 1).

Cultural aspects of entrepreneurial exit and business transfer yet remain to be further studied. DeTienne (2010) states that there are many different cultural aspects of entrepreneurial exit across the world and points out that research into cross-cultural entrepreneurial exit is necessary to better understand the processes, similarities and differences, inviting authors to further research. 
Figure 1: Factors influencing Croatian entrepreneurs to postpone their exit from the company

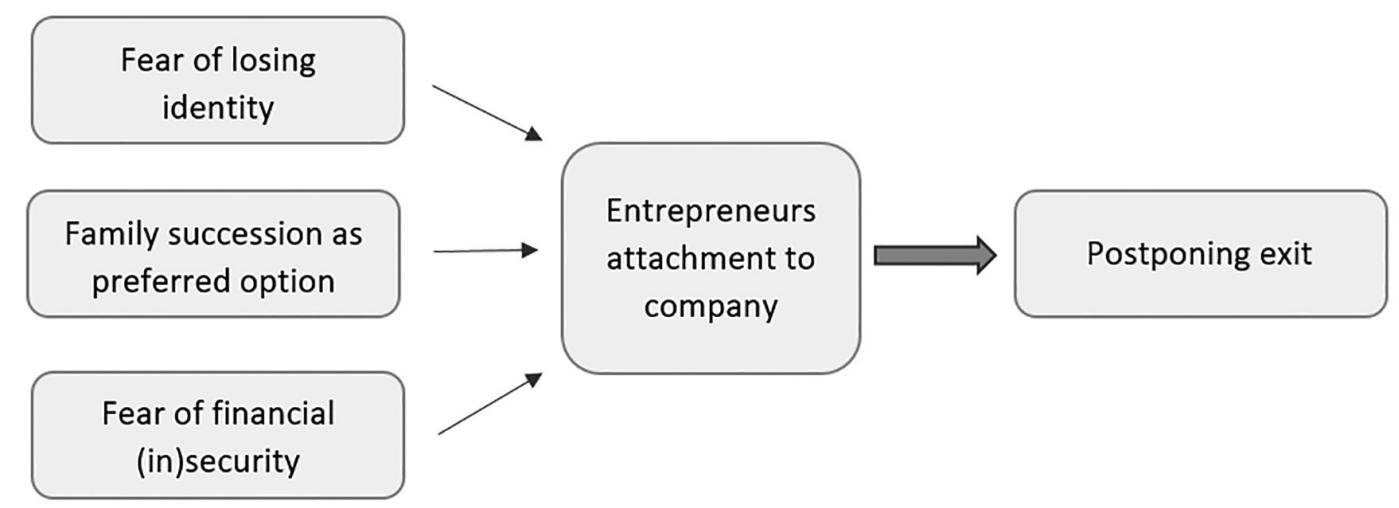

Source: Analysis of interview transcripts.

\section{Conclusion}

There is a significant number of ageing business owners in Croatia who will exit their companies in the coming years; almost one third of SMEs in Croatia are owned by owners who are 55 years and older. Considering the number of these entrepreneurs and the influence their exits can have on company stakeholders and national economy in general, it is of great importance to better understand the dilemmas they are facing when considering different exit strategies. The analysis of the interviews conducted with small business owners who are in the process of planning their exit strategy helped to identify the key challenges they face. The interviewed entrepreneurs show a strong emotional attachment to the firm that is even more pronounced with those entrepreneurs whose children are involved in the business. It was also found that the entrepreneurs have a strong preference for family succession even though their children might have already chosen different career paths. The entrepreneurs included in this research expressed their concerns about their financial security once they retire but, at the same time, due to cultural pressure, do not consider selling their company to their children as external buyers as an equally possible option as family succession without a financial compensation. Related to the previous findings, entrepreneurs are late in planning the business transfer, mostly because of relying too long on family successors. Additionally, they lack knowledge and experience in company valuation methods and have no information on the potential consultants providing that kind of expertise for micro and small companies.

Some of these challenges are contextual and the result of the undeveloped business transfer ecosystem and strong tradition and cultural values imposing family succession as the only dignified exit strategy for retiring company owners. Therefore, entrepreneurs often rely persistently on family succession as an exit strategy. In a situation when this strategy does not prove to be the right one, they have difficulty in changing the exit strategy due lack of time and channels that would link them with potential buyers. All of these findings were already addressed by the policy recommendations developed by CEPOR - SMEs and Entrepreneurship Policy Centre - in 2015. The most relevant action, based on this research, should be conducting awareness raising activities, targeting entrepreneurs, company stakeholders and wider public in order to develop the understanding of the challenges SME owners are facing when planning the business transfer. Company owners, stakeholders and the wider public should be open and flexible to accept non-family transfers as important exit strategies.

The results from this research contribute to a better understanding of the rationale and factors influencing ageing entrepreneurs when considering different exit strategies. A better understanding of the decision-making process of ageing entrepreneurs in the pre-transfer phase can contribute to creating and improving business transfer support policies. Evidence-based business transfer policies can contribute significantly to creating a fostering business transfer ecosystem and ensure the survival of small enterprises as well as safeguard the jobs which depend on them. Furthermore, the results can be useful to advisors in approaching and consulting ageing entrepreneurs in the preparatory phase of the business transfer process.

The limitations of this research lie in the limited number of interviews and in the fact that the research was conducted in a country with an undeveloped business transfer ecosystem, which influences the possibility of a wider generalization of the research results. Further research should provide a comparison of the research results from a country with a developed business transfer ecosystem in order to identify the influence of the culture and level of development of the national business transfer ecosystem on the identification of exit options of the entrepreneur. 


\section{References}

Aldrich, H. E. (2016). Perpetually on the eve of destruction? Understanding exits in capitalist societies at multiple levels of analysis. In D. R. DeTienne, Wennberg (Eds.), Research Handbook of Entrepreneurial Exit (pp. 11-41). Cheltenham, UK, Northampton, MA, USA: Edward Elgar Publishing. https://doi.org/10.4337/9781782546979

Alpeza, M., Grubisic, N., \& Mikrut, M. (2015). Business Transfer Barometer Croatia. Zagreb, Croatia: CEPOR - SMEs and Entrepreneurship Policy Centre.

Alpeza, M., Tall, J., \& Mezulic Juric, P. (2018). The Challenges of SME Business Transfers: The Evidence from Croatia and Finland. Organizacija, 51(2), 135-145. https://doi.org/10.2478/orga-2018-0012

Bennedsen, M., Nielsen, K. M., Pérez-González, F., \& Wolfenzon, D. (2007). Inside the family firm: The role of families in succession decisions and performance. The Quarterly Journal of Economics, 122(2), 647-691. https://doi.org/10.1162/qjec.122.2.647

Breton-Miller, I. L., Miller, D., \& Steier, L. P. (2004). Toward an Integrative Model of Effective FOB Succession. Entrepreneurship Theory and Practice, 28(4), 305-328. https://doi.org/10.1111/j.1540-6520.2004.00047.x

Croatian Pension Insurance Institute (2019). Retrieved from http://www.mirovinsko.hr/default.aspx?id=723

Dana, L. P., \& Ramadani, V. (2015). Family businesses in transition economies. Management, Succession and Internationalization. Switzerland: Springer International Publishing. https://doi.org/10.1007/978-3-319-14209-8

Delmar, F., Hellerstedt, K., \& Wennberg, K. (2006). The evolution of firms created by the science and technology labour force in Sweden 1990-2000. In: J. Ulhöi \& P. Christensen (Eds.), Managing Complexity and Change in SMEs (pp. 69-102). Cheltenham, UK, Northampton, MA, USA: Edward Elgar Publishing.

Deschamps, B. (2012). External takeover of small-and medium-sized enterprises: What do we know. Presented at Transeo Academic Awards 2012. Retrieved from http://www.transeo-association.eu/uploads/Academic\%20Awards/Deschamps\%20Abs.pdf

DeTienne, D. R. (2010). Entrepreneurial exit as a critical component of the entrepreneurial process: Theoretical development. Journal of Business Venturing, 25(2), 203-215. https://doi.org/10.1016/j.jbusvent.2008.05.004

DeTienne, D. R., \& Cardon, M. S. (2010). Impact of founder experience on exit intentions. Small Business Economics, 38(4), $351-374$. https://doi.org/10.1007/s11187-010-9284-5

DeTienne, D.R., \& Chandler, G.N.(2010). The impact of motivation and causation and effectuation approaches on exit strategies. Frontiers of entrepreneurship research, 30(1), 1.

Eisenhardt, K. M., \& Bourgeois III, L. J. (1988). Politics of strategic decision making in high-velocity environments: Toward a midrange theory. Academy of management journal, 31(4), 737-770. https://doi.org/10.5465/256337

Eisenhardt, K. M. (1989). Building theories from case study research. Academy of management review, 14(4), 532-550. https://doi. org/10.5465/amr.1989.4308385

European Commission (2002). Final Report of the Expert Group on the Transfer of Small and Medium Sized Enterprises, Brussels.

European Commission (2011). Business Dynamics: Start-ups, Business Transfers and Bankruptcy, Final Report, Brussels.

European Commission. (2013). Evaluation of the Implementation of the 2006 Commission Communication of Business Transfers. Brussels: CSES, DG Enterprise and Industry. (Ref.Ares (2014)180425 - 27/01/2014).

Eurostat (2019). Population structure and ageing - Statistics explained. Available at: https://ec.europa.eu/eurostat/statistics-explained/ index.php/Population_structure_and_ageing\#Past_and_future_population_ageing_trends_in_the_EU

Feldman, D. C., \& Beehr, T. A. (2011). A three-phase model of retirement decision making. American Psychologist, 66(3), 193-203. https:// doi.org/10.1037/a0022153

Flören, R.A., \& Nandram, S.S. (2007). Bedrijfsoverdracht in het MKB: een nieuwe stap voor de ondernemer. Neyenrode Business Universiteit. Cited in Weesie, E. (2017). Psychological Barriers In Business Transfers. How to cope with the transfer of SME ownership (Doctoral dissertation). University of Twente.

Harris, S. G., \& Sutton, R. I. (1986). Functions of parting ceremonies in dying organizations. Academy of Management journal, 29(1), 5-30. https://doi.org/10.5465/255857

Hytti, U., Stenholm, P., \& Peura, K. (2011). Transfers of business planning and bounded emotionality: a follow-up case study. International Journal of Entrepreneurial Behavior \& Research, 17(5), 561 - 580. https://doi.org/10.1108/13552551111158853

Ip, B., \& Jacobs, G. (2006). Business succession planning: a review of the evidence. Journal of small business and enterprise development, 13(3), 326-350. https://doi.org/10.1108/14626000610680235

Koładkiewicz, I., \& Wojtyra, M. (2016). Entrepreneurial Exit: Research Perspectives and Challenges. Problemy Zarządzania, 14(3 (62), t. 2 Rozwój badań nad przedsiębiorczością w kontekście globalnym), 89-106. https://doi.org/10.7172/1644-9584.62.6

Lansberg, I. (1988). The Succession Conspiracy. Family Business Review, 1(2), 119-143. https://doi.org/10.1111/j.1741-6248.1988.00119.x

Lansberg, I. (1999). Succeeding generations: Realizing the dream of families in business. Harvard Business Review Press.

Morris, M. H., Williams, R. O., Allen, J. A., \& Avila, R. A. (1997). Correlates of success in family business transitions. Journal of business venturing, 12(5), 385-401. https://doi.org/10.1016/S0883-9026(97)00010-4

Sarasvathy, S. D. (2004). The questions we ask and the questions we care about: reformulating some problems in entrepreneurship research. Journal of Business Venturing, 19(5), 707-717. https://doi.org/10.1016/j.jbusvent.2003.09.006

Sharma, P., Chrisman, J. J., Pablo, A. L., \& Chua, J. H. (2001). Determinants of Initial Satisfaction with the Succession Process in Family Firms: A Conceptual Model. Entrepreneurship Theory and Practice, 25(3), 17-36. https://doi.org/10.1177/104225870102500302 
Sharma, P., Chrisman, J. J., \& Chua, J. H. (2003). Predictors of satisfaction with the succession process in family firms. Journal of Business Venturing, 18(5), 667-687. https://doi.org/10.1016/S0883-9026(03)00015-6

Soleimanof, S., Morris, M. H., \& Syed, I. (2016). The role of retirement intention in entrepreneurial firm exit. In D. R. DeTienne \& K. Wennberg (Eds.), Research Handbook of Entrepreneurial Exit (pp. 157-183). Cheltenham, UK, Northampton, MA, USA: Edward Elgar Publishing. https://doi.org/10.4337/9781782546979

Steingold, F.S. (2012). The complete guide to sell your business. Berkeley: Nolo.

Taylor, M. P. (1999). Survival of the fittest? An analysis of self-employment duration in Britain. The Economic Journal, 109(454), $140-155$. https://doi.org/10.1111/1468-0297.00422

Van Teeffelen, L. (2010). Exploring success and failure in small firm business transfers. (Doctoral dissertation). Available from http:// repository.nyenrode.nl/record/8979

Van Teeffelen, L., Leroy, H. L., \& Uhlaner, L. M. (2011). What are the Main Drivers for Exit Choice in SME's: Owner or Firm Characteristics? Retrieved from: SSRN: https://ssrn.com/abstract=1866244

Van Teeffelen, L. (2012). Avenues to improve success in SME business transfers: reflections on theories, research and policies. Utrecht: Hogeschool Utrecht.

Van Teeffelen, L., \& Uhlaner, L. M. (2013). Firm resource characteristics and human capital as predictors of exit choice: An exploratory study of SMEs. Entrepreneurship Research Journal, 3(1), 84-108. https://doi.org/10.1515/erj-2012-0008

Viljamaa, A., Tall, J., Varamäki, E., Singer, S., \& Durst, S. (Eds.). (2015). Business Transfer Ecosystems and Awareness Raising Activities: Situation Analysis of Five European Countries. Seinäjoki: Seinäjoki University of Applied Sciences. Retrieved from https://www. theseus.fi/bitstream/handle/10024/97257/B108.pdf?sequence

Varamäki, E., Tall, J., \& Viljamaa, A. (2014). Business transfer and successions in Finland from the potential sellers' and predecessor's perspective. The entrepreneurship SIG at European Academy of Management: New Horizons with strong traditions. Advancing European Entrepreneurship Research: Entrepreneurship as a Working attitude, a mode of thinking and an everyday practice, 55-80.

Weesie, E. (2017). Psychological Barriers In Business Transfers. How to cope with the transfer of SME ownership (Doctoral dissertation). University of Twente.

Yin, R. K. (2014). Case study research: Design and methods, 5th edition. Sage publications.

\section{Starajoči se podjetniki in izzivi prenosa posla na Hrvaškem}

\section{Izvleček}

Prenos posla je kot raziskovalna tema pritegnil raziskovalce $v$ preteklih nekaj desetletjih. Prenos posla definiramo kot spremembo lastništva katerega koli podjetja drugi osebi ali pravni entiteti, ki zagotavlja kontinuiran obstoj in komercialno aktivnost podjetja ter obsega različne oblike transferjev tako družini kot tudi nedružinskim članom. Staranje in posledično upokojevanje se pogosto omenjata kot razloga za izstop podjetnikov iz podjetij in za namero začetka procesa prenosa posla. Uspešen proces prenosa posla je eden izmed ključnih predpogojev za dolgoročno trajnostnost malih in srednje velikih podjetij. Na Hrvaškem obstaja znatno število starajočih se lastnikov podjetij, ki bodo v prihodnjih letih izstopili iz svojih podjetij. Upoštevajoč število teh podjetnikov in vpliv, ki ga lahko ima njihov izstop na predstavnike interesnih skupin podjetja ter na nacionalno gospodarstvo kot celoto, je velikega pomena, da bi bolje razumeli dejavnike, ki lahko vplivajo na izbiro njihovih izstopnih strategij. Cilj članka je zagotoviti razumevanje dilem, s katerimi se soočajo starajoči se podjetniki, kadar razmišljajo o različnih oblikah izstopa. Podatke za študijo smo avtorji zbirali z globinskimi, polstrukturiranimi intervjuji, ki smo jih izvedli s šestimi starajočimi se podjetniki. Z analizami intervjujev smo identificirali izzive, s katerimi se soočajo podjetniki v procesu prenosa posla: čustvena navezanost na podjetje, močno dajanje prednosti družinskemu nasledstvu in skrb za finančno nasledstvo po upokojitvi. Nekaj od teh izzivov je rezultat nerazvitega ekosistema prenosa posla, močne tradicije in kulturnih vrednot, ki nakazujejo družinsko nasledstvo kot edino sprejemljivo izstopno strategijo za upokojene lastnike podjetij na Hrvaškem.

Ključne besede: prenos posla, podjetniški izstop, starajoči se podjetniki, mala in srednje velika podjetja, ekosistem prenosa posla 